\title{
Lipid Profile, Haematological Assay and Tissue Histology of Alloxan Induced Diabetic Wistar Rats Administered Extracts of Vernomia amygdalina (Bitter leaf) and Gnetum africanum (okazi leaf)
}

\author{
OSHOTSE, RB ${ }^{1}$; ${ }^{*}$ IFEANACHO, MO $^{2}$ \\ ${ }^{I}$ Department of Biochemistry, Faculty of Science, University of Port Harcourt, Nigeria \\ ${ }^{2}$ Department of Food, Nutrition and Home Science, Faculty of Agriculture, University of Port Harcourt, Rivers State, Nigeria \\ "Corresponding Author Email:mifeanacho@yahoo.com; Tel: +2348036779836
}

\begin{abstract}
Diabetes mellitus is predominant in numerous nations of the world with millions of deaths directly linked to it. The utilization of plants in providing answers to this pandemic has expanded over the years. This study investigated changes in some haematological parameters and tissue histology of alloxan induced diabetic Wistar rats administered combined leaf extracts (CLE) of vernonia amygdalina (bitter leaf (BI)) and gnetum africanum (okazi leaf $(\mathrm{OK})$ ). Aqueous extracts of bitter leaf and okazi leaf were prepared using the conventional method. Forty Wistar rats were grouped into eight of five rats each. Groups A and B were normal and diabetic control respectively, groups C to $\mathrm{G}$ ( diabetic groups) were treated with varied mixtures of extracts of vernomia amygdalina and gnetum africanum at $(10: 90 \mathrm{BI} / \mathrm{OK}),(30: 70 \mathrm{BI} / \mathrm{OK}),(50: 50 \mathrm{BI} / \mathrm{OK}),(70: 30 \mathrm{BI} / \mathrm{OK})$ and $(90: 10 \% \mathrm{BI} / \mathrm{OK})$ ratios respectively. Group $\mathrm{H}$, the diabetic control was administered the standard drug (Metformin). The animals were sacrificed on the $28^{\text {th }}$ day, blood samples and liver tissue were collected for biochemical analysis and histological examination. There was a significant $(\mathrm{p}<0.05)$ reduction in the lipid profile of the diabetic groups $(\mathrm{C}-\mathrm{G})$ especially in triglycerides with the highest reduction in $(50: 50 \mathrm{BI} / \mathrm{OK})$ combination $(0.70 \pm 0.07)$ while the least reduction was seen in $(30: 70 \mathrm{BI} / \mathrm{OK})$ combination $(1.37 \pm 0.08)$. There were time and ratio-dependent variations in the haematological indices. Hepatic histology showed evidence of varying levels of restoration of cellular structural integrity by the combined extracts. These results suggest that the combined extracts of vernomia amygdalina and gnetum africanum could be used to manage diabetes mellitus.
\end{abstract}

\section{DOI:https://dx.doi.org/10.4314/jasem.v25i7.1}

Copyright: Copyright $\left({ }^{\circ} 2021\right.$ Oshotse and Ifeanacho. This is an open access article distributed under the Creative Commons Attribution License (CCL), which permits unrestricted use, distribution, and reproduction in any medium, provided the original work is properly cited.

Dates: Received: 10 May 2021; Revised: 28June 2021; Accepted: 01 July 2021

Keywords: Extracts; bitter leaf; okazi leaf; diabetes; haematology; histology

Diabetes mellitus (DM) is portrayed as a disease syndrome with an accumulation of metabolic disorder described by chronic hyperglycemia which results from modifications in insulin secretion, insulin activity, or both(ADA,2013), Groop and Pociot, 2014). The body has firmly controlled mechanisms to keep the sugar level (BSL) normal. The BSL increases when nourishments containing starches like grains, sweet potato, cassava, Potatoes, bread, pasta, cakes and desserts are consumed. The carbohydrates are split into sugar and absorbed into the circulatory system, prompting an increase in BSL. At the point when the BSL rises, insulin secretion is stimulated in the body. Insulin is a hormone that acts as a key. It functions to drive glucose into the cells to be used either as energy or stored as fat. It therefore moderates blood glucose. If glucose level drops too low as in the cases of fasting, starvation or sustained physical exercises, the liver releases stored sugar to stabilize it. The customary treatment for DM is the administration of insulin or other hypoglycemic agents which help the diabetic maintain near normal carbohydrate, fat, and protein metabolism. There are advantages in the use of antidiabetic drugs like sulfonylureas, biguanides, and insulin (Eurich et al., (2013), Mohamad (2016)). However, like other synthetic drugs, they have limitations (Erasmus et al., 1999, Schramm et al., (2011)).Again, exercise and diet can likewise be utilized to manage DM although these techniques can be costly and have other limitations. World Health Organization (WHO 1985, 1994) endorsed the utilization of elective treatment, for the most part in countries where the right to regular guideline methods is inefficient.

Thus, the quest for legitimate hypoglycaemic and antihyperglycaemic agents that would not generate complications or negatively impact tissues became necessary. This study explored the impact of two staple- vegetables, bitter leaf (Vernonia amygdalina) and okazileaf (Gnetum africanum) extracts on the lipid profile, some haematological parameters and tissue histology of alloxan induced diabetic Wistar rats. 


\section{MATERIALS AND METHODS}

Collection and Identification of plant materials: Mature fresh leaves of bitter leaf and okazi leaf were bought from Choba market Port Harcourt. They were taken to the herbarium of the University of Port Harcourt, Choba, Rivers State Nigeria where they were identified and authenticated by the taxonomist.

Preparation of Plant Extracts: The extract was prepared using the method of Akah and Okafor, (1992). The leaves were washed separately, shadedried, and pulverized using an electric blender. Distilled water was added to the leaf powders. Then, the mixture was filtered using Whatman No.1 filter paper. The filtrate was concentrated using a water bath at a temperature of $50{ }^{\circ} \mathrm{C}$; then evaporated to dryness to give a dark green paste. The paste was reconstituted for the experiment. Forty Wistar rats were grouped into eight of five rats each

Procurement and Management of Experimental Animals: Forty (40) male Wistar rats weighing 150$180 \mathrm{~g}$ and bred at the animal house of the University of Port Harcourt, Rivers State were used. The rats were kept in stainless steel cages and allowed water and feed ad libitum. After 1 week of acclimatization, the treatment commenced and lasted for 28 days. Ethical conditions governing the conduct of experiments with life animals were strictly followed in accordance with the National Institute of Health Guide for the Care and Use of Laboratory Animals (NIH Publications No. 8023, revised in 1996).

Experimental design: The forty (40) Male Wister rats were randomly divided into eight groups A-H. Each group consisted of five rats. Diabetes was induced in the experimental rats of groups B-H while group A rats served as normal control. Upon establishment of diabetes, groups B-G were administered with the extract combinations ((10:90 BI/OK), (30:70 BI/OK), (50:50 BI/OK), (70:30 BI/OK) and (90:10 BI/OK) orally daily for 28 days while metformin was administered daily at $250 \mathrm{mg} / \mathrm{kg}$ body weight to the diabetic control group(group $\mathrm{H}$ ) via the same route.

Collection of Blood Sample: The animals were sacrificed on the 28th day and blood samples were collected into EDTA bottles for haematological analyses while plasma was used for biochemical determinations.

Biochemical Assay: The concentrations of triglycerides(TG), total cholesterol(TC), high density lipoprotein (HDL), low density lipoprotein (LDL), very low density lipoprotein (VLDL) were estimated using standard enzymatic kits (Atlas medical). The haematological estimations were done using haematological auto analyzer (Sysmex KX-21N) following the manufacturer's guideline.

Data Analysis: Data collected were subjected to analysis of variance (ANOVA). All results were expressed as Mean \pm Standard error, while the level of significance was set at $\mathrm{p}<0.05$.

\section{RESULTS AND DISCUSSION}

The results of the lipid profile test are presented in table 1. From the results, it was observed that the CLE caused a significant $(\mathrm{P}<0.05)$ decrease in the levels of some lipid parameters (TG, TC, LDL and VLDL) compared to the diabetic control group (negative control). High levels of these parameters constitute health risks such as elevated blood pressure (Shimizu et al., 2017). Group E (50/50BI/OK) showed the highest decrease in TG, TC, LDL and VLDL levels with $0.70 \pm 0.07,1.88 \pm 0.09,0.81 \pm 0.10$ and $0.31 \pm 0.03$ respectively. Group G (90/10BI/OK) equally showed the highest reduction in LDL concentration with $0.81 \pm 0.10$. An increase in HDL was observed, although not significant $(\mathrm{P}<0.05)$ compared to the diabetic control group. HDL is termed as good fat as it tends to clear off bad deposits of fats in and the around the linings of the circulatory tubes. Group $\mathrm{C}$ (10/90BI/OK) showed the highest rise in HDL with 1.27 \pm 0.06 . Aqueous leaf extracts of vernonia amygdalina and gnetum africanum separately have been documented to have anti-hypertriglyceridemic action in alloxan induced diabetic model (Akah and Okafor, 1992). Aqueous leaf extracts of vernonia amygdalina and gnetum afrcanum have also shown individually to have hypolipidemic effect in diabetic rats (Iliya et al., 2003). Acceptable glycemic management following vernonia amygdalina therapy has been shown to reduce VDL and total triglyceride levels (Huupponen et al., 1984). There was no significant decrease in serum cholesterol level of diabetic treated with the CLE (group D) compared to the diabetic control. The level of serum cholesterol has been documented to be decreased in diabetic rats treated with aqueous leaf extract of vernonia amygdalina (Gonzalez and Fevery, 1992), Nwanjo, 2005). Reduction in level of cholesterol that could improve renal and hepatic functions has been reported to be consistent with earlier report on hepatoprotective potentials of leaf extract of vernonia amygdalina in mice (Igile et al., 1995). There was a significant increase in serum HDL in the treated diabetic group compared to the diabetic control. This is consistent with earlier report on hepatoprotective potentials of leaf extracts of VA in mice. In this study, the use of CLE raised the HDL-Cholesterol on day 7 to 28 of the experimental animals compared to diabetic without 
treatment. Among the vital risk conditions for cardiovascular disease (CVD) includes a low level HDL-Cholesterol. The relationship between a low level of HDL-cholesterol and an elevated risk of CVD has been established through epidemiological and clinical studies (Assmann and Gotto, (2004). The protective effects of HDL cholesterol from CVD have been proposed to take place in various ways (Yokozawa et al., 2006). HDL exerts part of its antiatherogenic action by counteracting LDL oxidation and recent studies also showed that HDL encourages the inverse cholesterol movement pathway, by stimulating an efflux of excess accumulated cellular cholesterol and hinders the production of an oxidatively modified LDL (Yokozawa et al., 2006). In this study, the aqueous CLE may probably have showed the anti-atherogenic function through the raised HDL cholesterol. Significant reduction of serum LDL was also discovered in group B to $G$ (diabetic treated groups) compared to the diabetic group without treatment. This result corroborates with the finding of some researchers (Owen et al., 2011),( Imafidon and Okunrobo,2012) who observed decreased serum total cholesterol, triglycerol, Highdensity lipoprotein cholesterol (HDL-C) and Lowdensity lipoprotein cholesterol (LDL-C) levels by vernonia amygdalina extract in broiler chickens and rats respectively. Excess LDL-cholesterol could be discharged into the blood vessel walls and becomes a major constituent of atherosclerotic plaque lesions (Adaramoye et al., 2008). It is now widely believed that a profound signal for insulin secretion may be the link between glucose and lipid metabolism; and longterm exposure of islet cells to high levels of fatty acids result in $\beta$-cell dysfunction (lipotoxicity). Haematological indices results were presented in table 2 and 3 in their standard abbreviations.
There was observed rise in RBC, HCT and HGB in the treated groups compared with the diabetic control. Group F (70:30BI/OK) gave the highest values of RBC, HCT and HGB with 8.56 $\pm 0.50,49.72 \pm 3.26$ and $16.00 \pm 072$ respectively. The observed haematological effects were ratio dependent. Nutrient deficiencies that cannot be measured using anthropological parameters are often measured using hematological indices. A low count of certain hematological parameter is an indication of malnutrition. Low RBC and HCT generally are known as markers for anemia. The observed rise in the aforementioned mentioned haematological parameters showed that the CLE may have features that mimic haematinic actions thus can be employed to correct anaemia. The rise that is seen in total white blood cell (leucocytosis) showed inducing action on the immune system by the CLE. Therefore the consumption of the CLE may be useful in body defense to fight and protect against intruders. The rise seen in red blood cells count showed induced action on erythropoietin synthesis by the kidney and/or bone marrow for haematopoiesis (erythropoiesis).

The detected haematological effects may be ascribed to some of the phytochemical components of the leaves extract like flavonoids, tannins, terpenoids, saponins, proteins and steroids.

Flavonoids and tannins are phenolic compounds, and plant phenolics are a major group of compounds that behave as primary antioxidants or free radical scavengers". "Similarly, terpenoids, as vitamins, behave as regulators of metabolism and display a protective role as antioxidants".

\begin{tabular}{lllllll}
\multicolumn{7}{c}{ Table 1: Lipid profile of the rats administered the combined extracts } \\
\hline S/N & GROUP & $\begin{array}{l}\text { TG } \\
(\mathbf{m m o l} / \mathbf{L})\end{array}$ & $\begin{array}{l}\text { TC } \\
(\mathbf{m m o l} / \mathbf{L})\end{array}$ & $\begin{array}{l}\text { HDL } \\
(\mathbf{m m o l} / \mathbf{L})\end{array}$ & $\begin{array}{l}\text { LDL } \\
(\mathbf{m m o l} / \mathbf{L}\end{array}$ & $\begin{array}{l}\text { VLDL } \\
(\mathbf{m m o l} / \mathbf{L})\end{array}$ \\
\hline 1 & $\mathrm{~A}$ & $0.93 \pm 0.19^{\mathrm{b}}$ & $2.48 \pm 0.25^{\mathrm{b}}$ & $1.13 \pm 0.11^{\mathrm{c}}$ & $0.96 \pm 0.20^{\mathrm{c}}$ & $0.55 \pm 0.12^{\mathrm{c}}$ \\
2 & $\mathrm{~B}$ & $3.61 \pm 2.27^{\mathrm{a}}$ & $3.14 \pm 0.22^{\mathrm{c}}$ & $0.75 \pm 0.05^{\mathrm{c}}$ & $1.54 \pm 0.12^{\mathrm{c}}$ & $0.60 \pm 0.06^{\mathrm{c}}$ \\
3 & $\mathrm{C}$ & $1.37 \pm 0.08^{\mathrm{b}}$ & $3.20 \pm 0.11^{\mathrm{c}}$ & $1.27 \pm 0.06^{\mathrm{c}}$ & $0.844 \pm 0.14^{\mathrm{b}}$ & $0.62 \pm 0.04^{\mathrm{c}}$ \\
4 & $\mathrm{D}$ & $0.76 \pm 0.05^{\mathrm{b}}$ & $2.12 \pm 0.02^{\mathrm{b}}$ & $0.88 \pm 0.14^{\mathrm{c}}$ & $1.09 \pm 0.05^{\mathrm{c}}$ & $0.34 \pm 0.02^{\mathrm{c}}$ \\
${ }^{\mathrm{c}} 5$ & $\mathrm{E}$ & $0.70 \pm 0.07^{\mathrm{b}}$ & $1.88 \pm 0.09^{\mathrm{b}}$ & $1.07 \pm 0.06^{\mathrm{c}}$ & $0.81 \pm 0.10^{\mathrm{c}}$ & $0.31 \pm 0.03^{\mathrm{ab}}$ \\
6 & $\mathrm{~F}$ & $0.98 \pm 0.13^{\mathrm{b}}$ & $2.66 \pm 0.18^{\mathrm{c}}$ & $1.08 \pm 0.14^{\mathrm{c}}$ & $1.13 \pm 0.16^{\mathrm{c}}$ & $0.44 \pm 0.05^{\mathrm{c}}$ \\
7 & $\mathrm{G}$ & $0.98 \pm 0.08^{\mathrm{b}}$ & $2.46 \pm 0.08^{\mathrm{c}}$ & $1.25 \pm 0.06^{\mathrm{c}}$ & $0.81 \pm 0.06^{\mathrm{c}}$ & $0.44 \pm 0.03^{\mathrm{c}}$ \\
8 & $\mathrm{H}$ & $1.01 \pm 0.05^{\mathrm{b}}$ & $2.64 \pm 0.07^{\mathrm{c}}$ & $1.28 \pm 0.04^{\mathrm{c}}$ & $0.86 \pm 0.14^{\mathrm{c}}$ & $0.46 \pm 0.02^{\mathrm{c}}$ \\
\hline
\end{tabular}

Values are means \pm standard deviations for 5 rats per group $(n=5)$ Values in the same column with similar superscript letters are not significantly different at $5 \%$ level $(p<0.05)$. LEGEND::BI-Bitter leaf; OK-OkaziA= Normal control; $B=$ Negative control; $C=10: 90$ $B \mathrm{I} / O K ; D=30: 70 \mathrm{BI} / O K ; E=50: 50 \mathrm{BI} / O K ; F=70: 30 \mathrm{BI} / O K ; G=90: 10 \mathrm{BI} / O K ; \mathrm{H}=$ STANDARD DRUG (METHFORMI) 


\begin{tabular}{|c|c|c|c|c|c|c|c|c|c|c|c|}
\hline $\mathrm{S} / \mathrm{N}$ & GROUP & $\begin{array}{l}\text { RBC } \\
\left(\mathrm{x} 10^{6} \mathrm{~nm}^{3}\right)\end{array}$ & $\begin{array}{l}\text { MCV } \\
\text { (fl) }\end{array}$ & $\begin{array}{l}\text { RDW } \\
(\%)\end{array}$ & $\begin{array}{l}\mathrm{HCT} \\
(\%)\end{array}$ & PLT & MPV & PDW & PCT & LPCR & $\begin{array}{l}\text { WBC } \\
\text { (x100) }\end{array}$ \\
\hline 1 & A & $7.38 \pm 0.41^{\mathrm{c}}$ & $59.06 \pm 0.88^{c}$ & $16.82 \pm 0.51^{\mathrm{c}}$ & $43.60 \pm 2.66^{\mathrm{c}}$ & $489.00 \pm 39.25^{c}$ & $5.80 \pm 0.17^{\mathrm{c}}$ & $9.02 \pm 0.21^{\mathrm{c}}$ & $0.28 \pm 0.02^{\mathrm{c}}$ & $4.50 \pm 0.90^{\mathrm{c}}$ & $9.18 \pm 2.53^{\mathrm{c}}$ \\
\hline 2 & B & $6.70 \pm 0.52^{\mathrm{c}}$ & $58.45 \pm 0.75^{\mathrm{c}}$ & $16.90 \pm 0.10^{\mathrm{c}}$ & $41.00 \pm 0.70^{\mathrm{c}}$ & $837.50 \pm 43.50^{c}$ & $5.75 \pm 0.05^{\mathrm{c}}$ & $8.90 \pm 0.10^{\mathrm{c}}$ & $0.48 \pm 0.02^{\mathrm{c}}$ & $3.65 \pm 0.55^{\mathrm{c}}$ & $16.85 \pm 0.45^{\mathrm{c}}$ \\
\hline 3 & $\mathrm{C}$ & $7.67 \pm 0.39^{c}$ & $56.18 \pm 1.80^{c}$ & $17.58 \pm 0.65^{\mathrm{c}}$ & $42.96 \pm 1.38^{c}$ & $492.60 \pm 41.91^{\mathrm{b}}$ & $6.00 \pm 0.11^{\mathrm{c}}$ & $9.22 \pm 0.11^{\mathrm{c}}$ & $0.29 \pm 0.03^{\mathrm{c}}$ & $4.88 \pm 0.73^{\mathrm{c}}$ & $13.02 \pm 2.92^{\mathrm{c}}$ \\
\hline 4 & D & $8.51 \pm 0.37^{c}$ & $55.90 \pm 03.49^{\mathrm{a}}$ & $17.58 \pm 0.49^{c}$ & $47.22 \pm 1.87^{\mathrm{b}}$ & $\begin{array}{l}524.40 \pm 102.14 \\
\text { b }\end{array}$ & $5.90 \pm 0.11^{\mathrm{c}}$ & $9.16 \pm 0.16^{\mathrm{c}}$ & $0.30 \pm 0.05^{\mathrm{c}}$ & $4.18 \pm 0.73^{\mathrm{c}}$ & $11.66 \pm 2.30^{\mathrm{b}}$ \\
\hline 5 & E & $7.62 \pm 0.35^{\mathrm{c}}$ & $57.62 \pm 0.89^{\mathrm{c}}$ & $17.07 \pm 0.85^{\mathrm{c}}$ & $43.85 \pm 1.77$ & $667.75 \pm 69.68^{b}$ & $5.60 \pm 0.04^{\mathrm{c}}$ & $8.82 \pm 0.04^{\mathrm{c}}$ & $0.37 \pm 0.04^{c}$ & $3.05 \pm 0.32^{\mathrm{c}}$ & $7.97 \pm 1.24^{b}$ \\
\hline 6 & $\mathrm{~F}$ & $8.56 \pm 0.50^{c}$ & $57.90 \pm 0.69^{c}$ & $16.18 \pm 0.68^{c}$ & $49.72 \pm 3.26^{\mathrm{b}}$ & $536.40 \pm 33.66^{b}$ & $5.74 \pm 0.08^{c}$ & $8.90 \pm 0.09^{c}$ & $0.30 \pm 0.01^{\mathrm{c}}$ & $3.82 \pm 0.32^{\mathrm{c}}$ & $9.32 \pm 0.58^{b}$ \\
\hline 7 & G & $7.96 \pm 0.39^{c}$ & $55.90 \pm 1.55^{\mathrm{a}}$ & $17.60 \pm 0.31^{\mathrm{c}}$ & $44.40 \pm 1.47^{\mathrm{c}}$ & $475.75 \pm 38.21^{b}$ & $6.00 \pm 0.07^{\mathrm{c}}$ & $9.20 \pm 0.09^{c}$ & $0.28 \pm 0.02^{\mathrm{c}}$ & $4.20 \pm 0.33^{\mathrm{c}}$ & $8.551 .15^{b}$ \\
\hline 8 & $\mathrm{H}$ & $7.65 \pm 0.24^{\mathrm{c}}$ & $54.20 \pm 5.70^{\mathrm{a}, \mathrm{b}}$ & $19.15 \pm 1.95^{\mathrm{c}}$ & $41.35 \pm 3.05^{\mathrm{c}}$ & $463.00 \pm 40.00^{\mathrm{b}}$ & $6.75 \pm 0.75^{\mathrm{c}}$ & $10.80 \pm 1.60^{\mathrm{c}}$ & $0.30 \pm 0.01^{\mathrm{c}}$ & $6.75 \pm 2.25^{\mathrm{c}}$ & $10.75 \pm 0.75$ \\
\hline
\end{tabular}

Values are means \pm standard deviations for 5 rats per group $(\mathrm{n}=5)$ Values in the same column with similar superscript letters are not significantly different at $5 \%$ level (p<0.05). LEGEND::BI-Bitter leaf; OK-Okazi. $A=$ Normal control; $B=$ Negative control; $C=10: 90 \mathrm{BI} / \mathrm{OK} ; \mathrm{D}=30: 70 \mathrm{BI} / \mathrm{OK} ; \mathrm{E}=50: 50 \mathrm{BI} / \mathrm{OK} ; \mathrm{F}=70: 30 \mathrm{BI} / \mathrm{OK} ; \mathrm{G}=90: 10 \mathrm{BI} / \mathrm{OK}$; $H=S T A N D A R D$ DRUG $($ METHFORMI)

\begin{tabular}{|c|c|c|c|c|c|c|c|c|c|c|}
\hline $\mathbf{S} / \mathbf{N}$ & GROUP & $\begin{array}{l}\text { HGB } \\
(\mathrm{g} / \mathrm{dL})\end{array}$ & $\begin{array}{l}\text { MCH } \\
(\mathbf{g} / \mathbf{d L})\end{array}$ & $\begin{array}{l}\begin{array}{l}\text { MCHC } \\
\text { (g/dL) }\end{array} \\
\end{array}$ & LYM & GRAN & MID & LYMP & GRAP & MIDP \\
\hline 1 & $\mathrm{~A}$ & $14.38 \pm 0.71^{\mathrm{c}}$ & $19.60 \pm 0.19^{\mathrm{c}}$ & $33.24 \pm 0.41^{\mathrm{c}}$ & $7.24 \pm 2.04^{b}$ & $0.54 \pm 0.06^{\mathrm{c}}$ & $1.46 \pm 0.44^{\mathrm{c}}$ & $78.32 \pm 1.38^{\mathrm{c}}$ & $6.36 \pm 0.95^{\mathrm{c}}$ & $15.32 \pm 1.07^{\mathrm{c}}$ \\
\hline 2 & B & $13.80 \pm 0.10^{\mathrm{c}}$ & $19.75 \pm 0.45^{\mathrm{c}}$ & $33.80 \pm 0.30^{\mathrm{c}}$ & $12.45 \pm 0.35^{\mathrm{a}}$ & $0.95 \pm 0.05^{\mathrm{c}}$ & $3.45 \pm 0.75^{\mathrm{c}}$ & $74.15 \pm 4.05^{\mathrm{c}}$ & $5.75 \pm 0.05^{c}$ & $20.05 \pm 4.05^{c}$ \\
\hline 3 & $\mathrm{C}$ & $14.44 \pm 0.47^{\mathrm{c}}$ & $18.88 \pm 0.46^{\mathrm{c}}$ & $33.70 \pm 0.42^{\mathrm{c}}$ & $9.00 \pm 2.84^{\mathrm{c}}$ & $1.68 \pm 0.42^{\mathrm{a}}$ & $2.64 \pm 0.96^{\mathrm{c}}$ & $77.18 \pm 2.18^{\mathrm{c}}$ & $11.48 \pm 3.17^{\mathrm{ab}}$ & $11.28 \pm 1.70^{\mathrm{ab}}$ \\
\hline 4 & $\mathrm{D}$ & $15.54 \pm 0.51^{\mathrm{c}}$ & $18.34 \pm 0.55^{\mathrm{c}}$ & $33.04 \pm 1.08^{\mathrm{c}}$ & $9.38 \pm 2.05^{\mathrm{c}}$ & $0.52 \pm 0.13^{c}$ & $1.76 \pm 0.47^{\mathrm{c}}$ & $78.50 \pm 4.18^{\mathrm{c}}$ & $5.94 \pm 1.52^{\mathrm{c}}$ & $15.56 \pm 2.93^{\mathrm{c}}$ \\
\hline 5 & E & $14.90 \pm 0.47^{\mathrm{c}}$ & $19.57 \pm 0.35^{\mathrm{c}}$ & $34.00 \pm 0.26^{\mathrm{c}}$ & $5.80 \pm 1.18^{\mathrm{b}}$ & $0.77 \pm 0.12^{\mathrm{c}}$ & $1.40 \pm 0.14^{\mathrm{c}}$ & $71.05 \pm 4.12^{\mathrm{c}}$ & $10.85 \pm 2.69^{\mathrm{ab}}$ & $18.10 \pm 1.58^{\mathrm{c}}$ \\
\hline 6 & $\mathrm{~F}$ & $16.00 \pm 0.72^{c}$ & $18.74 \pm 0.24^{\mathrm{c}}$ & $32.40 \pm 0.66^{c}$ & $7.12 \pm 1.02^{b}$ & $0.38 \pm 0.03^{\mathrm{c}}$ & $2.60 \pm 1.35^{c}$ & $83.86 \pm 0.91^{\mathrm{a}, \mathrm{b}}$ & $3.90 \pm 0.37^{\mathrm{ab}}$ & $12.18 \pm 0.84^{b}$ \\
\hline 7 & G & $15.05 \pm 0.39^{\mathrm{c}}$ & $18.97 \pm 0.49^{\mathrm{c}}$ & $33.95 \pm 0.53^{\mathrm{c}}$ & $6.55 \pm 1.21^{\mathrm{b}}$ & $0.77 \pm 0.27^{\mathrm{c}}$ & $1.22 \pm 0.22^{\mathrm{c}}$ & $75.37 \pm 6.25^{\mathrm{c}}$ & $10.30 \pm 3.39^{\mathrm{ab}}$ & $14.32 \pm 3.04^{\mathrm{c}}$ \\
\hline 8 & $\mathrm{H}$ & $14.05 \pm 0.85^{\mathrm{c}}$ & $18.45 \pm 1.75^{\mathrm{c}}$ & $34.05 \pm 0.35^{\mathrm{c}}$ & $9.10 \pm 0.50^{\mathrm{b}}$ & $0.40 \pm 0.10^{\mathrm{c}}$ & $1.25 \pm 0.15^{\mathrm{c}}$ & $85.35 \pm 1.25^{\mathrm{a}, \mathrm{b}}$ & $4.05 \pm 0.75^{\mathrm{a}}$ & $10.60 \pm 0.50^{\mathrm{ab}}$ \\
\hline
\end{tabular}

Values are means \pm standard deviations for 5 rats per group $(\mathrm{n}=5)$ Values in the same column with similar superscript letters are not significantly different at $5 \%$ level $(\mathrm{p}<0.05$ ) .LEGEND::BI-Bitter leaf;OK-OkaziA= Normal control; $B=$ Negative control; $C=10: 90 \mathrm{BI} / \mathrm{OK} ; \mathrm{D}=30: 70 \mathrm{BI} / \mathrm{OK} ; \mathrm{E}=50: 50 \mathrm{BI} / \mathrm{OK} ; \mathrm{F}=70: 30 \mathrm{BI} / \mathrm{OK} ; \mathrm{G}=90: 10 \mathrm{BI} / \mathrm{OK} ;$ $H=S T A N D A R D$ DRUG (METHFORMI) 
Antioxidants are crucial in the hindrance of oxidative stress. "They prevent chain reactions activated by free radicals by eliminating free radical intermediates and suppressing other oxidation reactions". There is great, commercially driven promotion of saponins as dietary supplements and nutriceuticals. Literature has shown that ingestion of certain phytochemical compounds can normalize the hematological abnormalities associated with diabetes mellitus. Akah et al.,(2009), Atangwho, et al.,(2010) in their investigation of the
Effect ofvernonia amygdalina on biochemical and hematological parameters in diabetic rats, reported that vernonia amygdalina is an agent capable of normalizing the hematological abnormalities associated with diabetes mellitus.Opara et al.,(2012),investigated the haematological and biochemical responses of rabbits to aqueous extracts of Gmelina arborea leaves and reported that the extract enhanced the haematological responses of the rabbits.

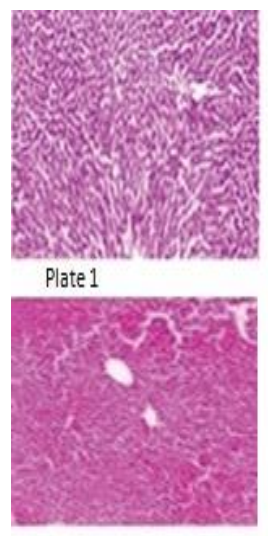

Plate 4

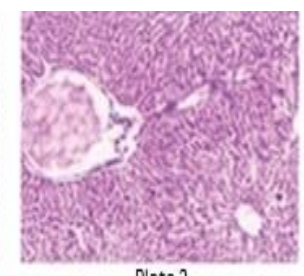

Plate 2

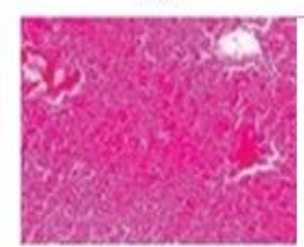

Plate 5

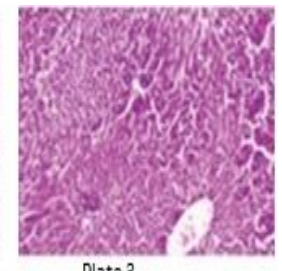
Plate 3

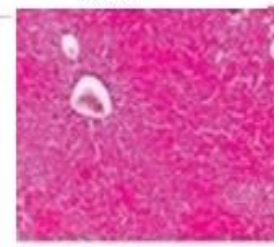

Plate 6

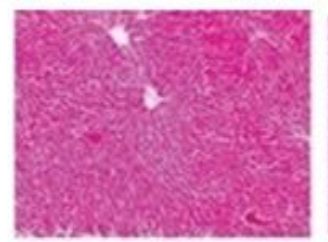

Plate 7

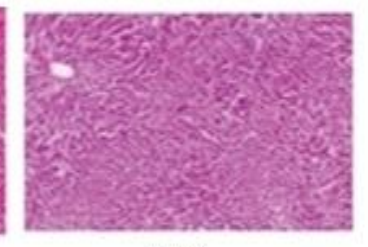

Plate 8

Fig 1(Plates 1 to 8 ) histological examination of the liver tissue magnification $\times 400$

Historical results of the hepatic tissues of the experim Ental animals are represented in Plates 1-8. The positive control group (Plate 1)showed liver parenchyma with general structures preserved, including hepatic lobules with normal hepatocytes surrounded by sinusoids and distributed radially towards the centrilobular veins, and containing Kupffer and red blood cells in the capillary lumen. Portal spaces were also normal, with no observed inflammatory infiltration, fatty degeneration or abnormal distribution of fibroblasts or collagen in rats.The negative control (Plate 2) presented morphological changes in the liver. These changes were characterized by hepatocytes that contained focal or generalized fatty vacuoles and micro or macro vesicular features that were associated with the presence of dilated sinusoids and a progressive loss of general organ structure. Inflammatory changes consistent with steatohepatitis, which were represented by mononuclear inflammatory infiltrates of moderate intensity, were observed in the interlobular and periportal spaces in $40 \%$ of analyzed liver histological sections. The diabetic group treated with the standard drug (Metformin) (Plate 8) showed normal portal triad (hepatic arteriole, portal venule and bile duct) and normal cords of hepatocytes. This impression is a normal histology. The architecture of hepatic parenchyma in the treatment groups, (10:90BI/OK), (30:70 BI/OK), (50:50BI/OK), (70:30 $\mathrm{BI} / \mathrm{OK}$ ) and (90:10\% BI/OK) (Plates 3--7) showed evidence of varying levels of necrosis and restoration of cellular integrity. There is therefore a gradual healing and clearance of the observed tissue necrosis and the inflammation in the liver. The group administered with (30/70BI: OK) had lowest level of cellular necrosis and inflammation of the liver. These findings corroborate with the work of Atangwho et al., (2007), Oluwole Akinola et al., (2011), Atangwho et $a l ., 2016)$. They investigated the effects of leaf extract of Vernonia amygdalina singly and in combination with Azadirachta indica on hepatic morphology and hepatotoxicity markers in streptozotocin- induced 
diabetic and in alloxan-induced hyperglycaemic rats. Some of the researchers observed no striking differences in the hepatic morphology of the control and the treated groups, others reported varying degrees of reversal of cellular structural alterations by the extracts.

Conclusions: The results showed that the combined leaves extracts have hypocholesterolaemic potentials. Since dyslipidaemia occurs in many diabetic patients, the use of lipid-lowering substances is now recommended for diabetic treatment and the results suggest that these combined aqueous leaf extract could be helpful in this regard. In addition, the study suggests that the combined leaf extracts could protect the liver against impairment due to diabetes. The study, therefore, confirms the folklore use of the leaves in the management of diabetes.

\section{REFERENCES}

Adaramoye, OA; Akintayo, O; Achem, J; Fafunso, MA (2008). Lipid lowering effects of meth anole extracts of $V$. amygdalina leaves in rats fed on high cholesterol diet. Vasc. Health Risk Manage. 4, 236-241.

Akah, PA; Alemji, JA Salawu, OA; Okoye TC; Offiah, NV (2009) Effect of vernonia amygdalina on Biochemical and Hematological Parameters in Diabetic Rats. Asian J. Med. Sci. $1(3)$ : $108-113$,

Akah, PA; Okafor, CL (1992). Blood sugar lowering effect of Vernonia amygdalina Del. in an experimental rabbit model. Phytother Res. 6: 171173.

America diabetes association (ADA). (2013) .Diabetes care; 36 (Supplrment 1): S11-S66.

Assmann, G; Gotto, AM. (2004). HDL cholesterol and protective factors in atherosclerosis. Circulation 109(23 Suppl 1):III8-14

Atangwho, IJ; Ebong, PE; Eteng, MU; Eyong, EU; Obi, AU (2007). Effect of Vernonia amygdalina Del. leaf on kidney function of diabetic rats. Int. J. Pharmacol. 3: 143-148.

Atangwho, IJ; Ebong, PE; Eyong, EU; Asmawi, MZ; Ahmad, M. (2016).Synergistic antidiabetic activity of Vernonia amygdalina and Azadirachta indica: Biochemical effects and possible mechanism. J. Ethnopharmacol. 193:725-731.
Atangwho, IJ; Ebong, PE; Eyong, EU; Eteng, MU (2010). Combined administration of extracts of Vernonia amygdalina(Del) andAzadirachta indica (A. Juss) mimic insulin in time-course body weight and glucose regulation in diabetic and non-diabetic rats.Nigerian .J. Biochem. Mol. Biol. 25(1):44-49

Erasmus, R; Blanco, EB; Okesina, AB (1999). Assessment of glycemic control in stable type I Black South African Diabetics attending a preurban clinic. Postgrad. Med. J.75: 603-06.

Eurich, DT; Weir, DL; Majumdar, SR; Tsuyuki, RT; Johnson, JA; Lisa Tjosvold, L (2013) Comparative safety and effectiveness of metformin in patients with diabetes mellitus and heart failure systematic review of observational studies involving 34000 patients. Circ Heart Fail 6: $395 \mathrm{e} 402$.

Gonzalez, J; Fevery, J (1992). Spontaneously diabetic biobreeding rats and impairment of bile and independent bile flow and increased biliary bilirubin, calcium and lipid secretion. Hepatology, 16: 426-432

Groop, L; Pociot, F (2014). Genetics of diabetes - Are we missing the genes or the disease? Mol Cell Endocrinol. 382:726-739.

Huupponen, RK; Viikari, JS; Saarima, H (1984). "Correlations of serum lipids with diabetes control in sulphonyhurea treated diabetic patients. Diabetes Care 7: 575-578

Igile, GO; Wieslaw, O; Burda, S; Jurzysta, M (1995). Nutritional assessment of Vernonia amygdalina leaves in growing mice. J. Agric. Food Chem. 43: 2162-2166.

Iliya, I.; Tanaka, T; Ali, Z.; Iinuma, M.; Furusawa, M.; Nakaya, K.; Shirataki, Y; Murata, J; Darnaedi, D; Matsuura, N; Ubukata, M (2003) Six flavonostilbenes from Gnetum africanum and Gnetum gnemon. Heterocycles; 60:159-166.

Imafidon, EK; Okunrobo, OL (2012). Effects of Vernonia amygdalina Del. Extract on Cholesterol Level and Lipid Peroxidation Status in Rats Given Red Dye Adulterated Palm Oil Diets. Br. J. Pharm. Res. 2(2): 98-107.

Izevbigie, EA; Bryant, JL; Walker, A (2004). A novel natural inhibitor of extracellular signal-regulated kinases and human breast cancer cell growth. Exp. Biol. Med. (Maywood). 229: 163-169. 
Maxwell, NO; Tobechukwu, CI; Mbah, GU; Idorenyin, FE; Ifeanyi, PO; Abayomi, KO; Ifeanyi, CO (2012). Haematological and biochemical responses of rabbits to aqueous extracts of Gmelina arborea leaves. Aquac Aquar Conserv Legis

Mohamad,SA (2016). Diabetes and oral therapies A review of oral therapies for diabetes mellitus.J.Tar.Univ.Med.Sc. 11(4):317-329

Nwanjo, HU (2005). Efficacy of aqueous leaf extract of Vernonia amygdalina on plasma lipoprotein and oxidative status in diabetic ratmodels. Niger. J. Physiol. Sci. 20(1-2): 39-42.

Oluwole, BA; Omotso, GO; Akinola, OS; Olunfunke, OD; Adewoye, TE (2011) Effects of combined leaf extract of Vernonia amygdalina and Azadirachta indica on hepatic morphology and hepatotoxicity markers in streptozotocin- induced diabetic rats. Chin. J. Intergr. Med. 9(12):45-52.

Opara, MN; Iwuji, TC; Mbah, GU; Etuk, IF; Ogbuewu, IP; Olaifa, AK; Okoli, IC (2012) Haematological and biochemical responses of rabbits to aqueous extracts of Gmelina arborea leaves. Rabbit Genetics 2:5-9

Owen, OJ; Amakiri, OA; Karibi-Botoye, TA (2011). Lipid - lowering effects of bitter leaf (Vernonia amygdalina) in broiler chickens fed finishers' mash. Agr Biol J N Am. 2(6): 1038-1047
Schramm, TK; Gislason, GH; Vaag, A; Rasmussen, JN; Folke, F; Hansen, LM (2011) Mortality and cardiovascular risk associated with different insulin secretagogues compared with metformin in type 2 diabetes, with or without a previous myocardial infarction: a nationwide study. Eur Heart J 2011; 32: 1900e1908

World Health Organization study group on diabetes mellitus (WHO). (1985). Technical report series No. 727. World Health Organization, Geneva.pp.1-108.

World Health Organization study group on diabetes mellitus (WHO). (1994). Technical report series No. 844, World Health Organization, Geneva, 78 -79 .

Yokozawa, T; Cho, EJ; Sasaki, S; Satoh, A; Okamoto, $\mathrm{T}$ (2006). The protective role of Chinese prescription Kangen-karyu extract on dietinduced hypercholesterolemia in rats. Biol Bharm Bull. 29: 760-765.

Yuji, S; Shimpei, S; Yuko, N; Jun, K; Hirotomo, Y; Mako, N; Koichiro, K; Shin-Ya,K; Yasuhiro,N; Takahiro, M (2017). Triglycerides and blood pressure in relation to circulating CD34-positive cell levels among community-dwelling elderly Japanese men: a cross-sectional study. Envr. Heal. Prev. Med. 22:77 DOI 10.1186/s12199017-0684-x 